\title{
Pornography in print media: Legal review of pornographic content on Mantra Tabloid in Indonesia
}

\author{
Supadiyanto Supadiyanto \\ College of Communication Studies (STIKOM) Yogyakarta, Indonesia \\ Email:padiyanto@yahoo.com
}

\begin{abstract}
Cases of pornography are rife in various media, including print media, into severe problems because pornographic content harms public behavior. Especially for teenagers and children. The main problem is: what is the legal review of pornographic content in the Mantra Tabloid? The research paradigm uses quantitative-data collection techniques by content analysis, documentation, and literature review. Two types of data are processed: primary data (document Mantra Tabloid of 170th Edition) and secondary data (literature study). The result, Tabloid Mantra legitimately contain pornographic content. The women exposed in the Mantra Tabloid became the object of sex as well as victims. The result of content analysis from Tabloid Mantra is corroborated by the Press Council's decision, which gives sanction (written warning). In the future, the research results should be followed up by a lawsuit against the managers of Tabloid Mantra through the court.
\end{abstract}

Keywords: Pornography, Content, Woman, Object, Mantra Tabloid

\section{Introduction}

Pornography becomes a serious issue for the media industry. The rise of pornography cases contained in various types of media shows how awareness of media workers in presenting positive content is still low. The growth of the 
media industry, was not balanced by law enforcement efforts in Indonesia. Law enforcement on pornography cases in print media, television media, radio media, internet media and social media is still very low due to its relatively soft regulation.

On the one hand, crime cases do not diminish. Cases of murder, rape, sexual harassment, fraud, infidelity, robbery, theft, until corruption are still a social fact that can not be underestimated in this country. We ought to be concerned about all that. Because there is relevance between the rise of pornography in the media and the rise of crime in Indonesia.

Based on online tracking, the problem of pornography has become a popular public consumption. Evidently, when researchers typed the word porn on Google's site found as many as 1,390 million links in just 0.19 seconds. The word pornography itself tracked as many as 14.4 million citation in 0.28 seconds. While the sex word as many as $380,000,000$ links (within 0.24 seconds), sex videos as much as 205 million links ( 0.23 seconds); porn videos as much as $879,000,000$ citation ( 0.34 seconds), and pornographic videos as much as $12,100,000$ citation ( 0.26 seconds). The number of sex word citation, even beat the number of word citation Joko Widodo (President of the Republic of Indonesia) which only penetrated the number $22,500,000$ pieces $(0.56$ seconds). The above figures show that pornography has become a material of public consumption, especially in the internet media. Pornography can pose a serious threat to the public's future.

In the context of media oversight in Indonesia, there has been a Press Council, the Indonesian/Local Broadcasting Commission, the Ministry of Communication and Informatics, and the Film Censorship Institution. But still, pornographic cases are still easily found in various media, including in print. The main problem in this research is: how is the legal review of pornographic content in Mantra Tabloid?

\section{Methods}

The paradigm or type of research is quantitative (positivistic). Quantitative research paradigm selected by researchers to detect and know pornographic content presented in Mantra Tabloid. Technical data collection is done by way of documentation, content analysis, and literature review. Quantitative content analysis focuses research on calculating and accurately measuring aspects or dimensions of the text (Eriyanto, 2015: 4). Two types of data are processed in 
research that is primary data (derived from the document Mantra Tabloid of 170th edition) and secondary data (derived from the results of literature review). The time of this research is done from October 2017 until September 2018 (12 months). Research location in Yogyakarta.

Data analysis is done by analyzing of regulation of the news content on the Mantra's Tabloid. The object of research is limited to Mantra Tabloid of 170th edition which is published on 11-24 October 2017. Mantra Tabloid published by PT. Ubedde Media Adhiwarta with SIUPP: 1142/SK/MENPEN/ SIUPP/1999.

Director/Responsible Person: H. Zubairi Indro and Chief Editor: Suwito Hadi “Danar Espe”. Editor's address: Jalan Gayung Kebonsari No. 16 Surabaya East Java Telp.: (031) 8290955, 8291004 Fax: (031) 8290874 Jakarta: Graha Pena Lt 5 Jalan Kebayoran Lama No. 12 South Jakarta Telp. (021) 53699625 Fax: (021) 53651170; E-mail: mantra.tabloid@gmail.com

\section{Literature Review}

Principally, the true meaning of pornography is the knowledge of reading or film and the like which aims to arouse sexual desire; depictions of erotic behavior (Umi Chulsum and Windy Novia, 2006). While Echols, John M and Hassan Shadily (1992: 439) interpret pornography as obscenity, porn, obscene images/readings. In the Arabic Dictionary (Bisri, Adib and Munawwir A. Fatah, 1999: 269), the equivalent of pornography is "al-adaba au alfannul ibaakhiyyun; kataabaatun au suwarun daa'irotun" (page 269).

While the equivalent of the word pornography in the Java language is "saru = ora pantes" (Mangunsuwito, 2014: 157). According to Law No. 44 of 2008 on Pornography Article 1, paragraph 1, pornography is defined as pictures, sketches, illustrations, photographs, writings, sounds, sounds, moving pictures, animations, cartoons, conversations, gestures, or other forms of messages through various forms of media communications or public performances, containing obscenity or sexual exploitation that violates the moral norms of society.

Pornography becomes very closely related to the presence of mass media. Because through the presence of mass media, pornography becomes so easy to greet anyone who wants it. Internet for example. Government in this context the state can barely do anything with the medium of the Internet. This Internet technology becomes an extraordinary medium capable of crashing the boundary 
of the state. The Internet makes communication connections no longer sealed by space and time limits. Marshall Mc Luhan (Canada) in the 1960's once initiated the concept of a global village; which is now a globalization thanks to the implementation of Telematikagratrans.

The quality of the press at this time also can not be free from pornography. Press media makes women as a treat "soft" to attract readers as well as advertisers. Pay attention to how the press media logic, let alone broadcast media works by presenting artists, cast, newscasters, show hosts and the like with sexy underwear? The ads were sprinkled with advertising stars that are not less "sexy". Product ads that have nothing to do with women's products, to attract the attention of female characters as their advertising stars.

Particularly in the television media industry, interesting data shows that nine ads served in a single time the opportunity to serve ads, there is only one ad that does not involve women. Thus the woman is very attached to the ad. Women have become their own commodities (Widyatama and Siswanta, 1997, 1998, 2001; Widyatama, 2002, 2004).

Although occupying a large number, but the portrayal tends to be just as sex object and subordinate or experiencing gender bias (Judith and Elis, in Marry Cross, 1996).

According to Herbert Rittlinger (1972), physically women in all parts of his body ranging from the hair, face, neck, to the toe has its own beauty so as to foster extraordinary attraction. Not surprisingly, women become the favorite target of the photographer and cameraman. Even according to Budi Sampurno (1992) in Widyatama (2009), not only posture, hair to foot tip, female attraction can also be seen from his behavior. Everything can be an attraction both fellow women and men. That's the main reason why many women are involved in advertising, so the ads will have its own beauty. The beauty that women have in their daily life forms a stereotype and brings them to the properties around that beauty. Among other things that women should appear charming, clever housekeeping, cooking, appear prima to please the husband and deserve to be invited to various events (Kompas No. 51, 1999), intelligent and a source of knowledge and family morale (Bungin, 2002: 128) guardians of fine and noble values at home, heredity, weakness, graceful, skilled at cooking, more emotional, less powerful physical, agile, motherly, spoiled (Martadi, 2001), unreliable, dependent, passive, weak, cowardly described as objects sexually, with emphasis on beautiful figures and clothing (Suharko, 1998). 
There are at least four criticisms at once from two paradigms of structural feminism and conflict paradigm feminism that have four sub-streams to explore about content that makes women "media stage sweeteners". First, in terms of criticism of liberal feminism; the mass media makes women merely the object of sexual encounter for men.

Second, in terms of criticism of radical feminism, the mass media makes women appear as sexy, beautiful, long-haired, white, gentle, graceful, passive, inactive in intercourse, inferior, physically weak, dressed in minimalism and invites lust for the opposite sex, all of whose bodies are identical to commercials and commercials, working in the privacy or domestic sphere, not protesting, subject to sexual humor, a person who must be mentally prepared to become second wife and so on, and other stigmatizations.

Third, in terms of criticism of social feminism, the mass media makes women as an instrument of capitalism and patrialism in strengthening its power in life in this world. Fourth, in terms of criticism of Marxist feminism, the mass media made women "second class". For they are simply a tool of capitalism to make the most profit from the powerful "Exla" drug business; not the real owner of capitalism (Supadiyanto, 2014).

So who can stem the threat of pornography is now really real in front of the eye, in the hand gang? The country? Regulatory? Mass media companies? Public? Or who are?

\section{Results and Discussion}

\section{Content Analysis of Mantra Tabloid of 170th Edition}

The Mantra Tabloid of 170th edition consists of 32 pages. Of the 32 pages, there are 16 pages that have been detected to publish content that contains pornography and eroticism vulgarly. Given that half (16 pages out of 32 pages) of the print media content is full of obscene, pornographic, and erotic news and information (text and photos). As for the findings of the facts from the Mantra Tabloid of 170 th edition as follows: 
Journal of Social Studies (JSS), Volume 15, Number 1, 2019: 47-62

Table 1: Content analysis table of Mantra's Tabloid of 170th Edition

\begin{tabular}{|c|c|c|c|}
\hline Page & $\begin{array}{l}\text { Name of } \\
\text { Rubric }\end{array}$ & Title of News & Content/Discription \\
\hline 1 & Cover & $\begin{array}{l}\text { Seks Belok Komunitas } \\
\text { Lesby; Nikah Sirri } \\
\text { \& Prostitusi Gaya } \\
\text { Baru Artis; Kisah } \\
\text { Pemuda Kencur } \\
\text { Nikahi Nenek; Oknum } \\
\text { PNS Asyik Indehoy } \\
\text { di Hotel Digerebek } \\
\text { Suami; Tobat Bandot } \\
\text { Seks Pemburu Janda; } \\
\text { Tawaran Syahwat } \\
\text { PSK Alas Roban; } \\
\text { Gairah Seks Wanita } \\
\text { Ala Primbon Jawa; } \\
\text { Elizabeth Angela } \\
\text { Lorenza, Hot dengan } \\
\text { Pria Berkeringat. }\end{array}$ & $\begin{array}{l}\text { - The cover title is bombastic } \\
\text { (provocative). } \\
\text { - Displaying a half-body photo } \\
\text { of Elizabeth Angela Lorenza } \\
\text { wearing underwear (looks } \\
\text { like a pair of breasts). }\end{array}$ \\
\hline 3 & Hot News & $\begin{array}{l}\text { Sensasi Elizabeth } \\
\text { Angela Lorenza, } \\
\text { Berbagi Tips } \\
\text { Posisi Intim Hot; } \\
\text { Suka dengan Pria } \\
\text { Berkeringat? }\end{array}$ & $\begin{array}{l}\text { The photo of Elizabeth Angela } \\
\text { Lorenza wearing BH and her } \\
\text { navel and thigh look. Contains } \\
\text { about Elizabeth Angela Lorenza's } \\
\text { profile and brief information on } \\
\text { extreme sex positions. }\end{array}$ \\
\hline 5 & $\begin{array}{l}\text { Laporan } \\
\text { Khusus }\end{array}$ & $\begin{array}{l}\text { Wow Komunitas } \\
\text { 'Belok' Makin Marak, } \\
\text { Ada yang Eksklusif } \\
\text { dan Urakan; Melihat } \\
\text { Tamsil Cinta Kaum } \\
\text { Lesbian } \\
\end{array}$ & $\begin{array}{l}\text { Contains special Lesbian } \\
\text { coverage. }\end{array}$ \\
\hline
\end{tabular}




\begin{tabular}{|c|c|c|c|}
\hline Page & $\begin{array}{l}\text { Name of } \\
\text { Rubric }\end{array}$ & Title of News & Content/Discription \\
\hline 8 & $\begin{array}{l}\text { Mistik } \\
\text { Artis }\end{array}$ & $\begin{array}{l}\text { Roro Fitria, Lakoni } \\
\text { Ritual } 1 \text { Suro; Misteri } \\
\text { Kekayaan Melimpah } \\
\text { hingga Efek Mistik } \\
\text { Rumah. }\end{array}$ & $\begin{array}{l}\text { Contains about the profile of } \\
\text { Roro Fitria on display also three } \\
\text { photos from Roro Fitria which } \\
\text { is performing a ritual } 1 \text { Suro; } \\
\text { was in a car, and was sitting in a } \\
\text { chair wearing a bra and panties } \\
\text { (bathing suit) only. }\end{array}$ \\
\hline $10-11$ & $\begin{array}{l}\text { Kamasu } \\
\text { tra }\end{array}$ & $\begin{array}{l}\text { Saatnya Menikmati } \\
\text { "Standing Sex" } \\
\text { Sensasi Dahsyat \& } \\
\text { Nikmat; Humor } \\
\text { Sutra, Pembantu dan } \\
\text { Kondom Bekas; Kakak } \\
\text { Makan Belut; Jamu } \\
\text { Khusus Pria, Greng } \\
\text { Plus TL; Rahasia } \\
\text { Gairah Seks Wanita } \\
\text { ala Primbon Jawa, Tipe } \\
\text { Seroka Bergoyang, } \\
\text { Mitos Istri Setia; } \\
\text { Membikin Wanita } \\
\text { Kelojotan }\end{array}$ & $\begin{array}{l}\text { Contains on how to have sex } \\
\text { while standing; funny sex stories; } \\
\text { Javanese sex myth; and tips to get } \\
\text { women to reach orgasm in sex. }\end{array}$ \\
\hline
\end{tabular}

13 Selingk uh Awas, Bila Istri Sering It contains stories of infidelity Ditinggal Jaga Malam,

Bisa Jadi Diserobot

Tetangga; Misteri

Dompet dalam

Perselingkuhan, Karena

Tertinggal Aksi Mesum

Terbongkar.

18 Kronik Oknum PNS Digerebek It contains story of infidelity

Saat Indehoy dengan

Debt Collector 


\begin{tabular}{|c|c|c|c|}
\hline Page & $\begin{array}{l}\text { Name of } \\
\text { Rubric }\end{array}$ & Title of News & Content/Discription \\
\hline 19 & Sabrang & $\begin{array}{l}\text { Fenomena Gadis } \\
\text { Bokingan Karaoke di } \\
\text { Tarakan; Long Time } \\
\text { Rp } 3 \text { Juta, Short Time } \\
\text { Rp 1,5 juta; Tragedi } \\
\text { Pemerkosaan Dramatis } \\
\text { \& Disaksikan Suami; } \\
\text { Awas, Sopir Taksi } \\
\text { Online Paksa Wanita } \\
\text { Begituan }\end{array}$ & $\begin{array}{l}\text { Contains about Commercial Sex } \\
\text { Workers in Tarakan; news of } \\
\text { rape and robbery; misbehavior } \\
\text { / harassment by an online taxi } \\
\text { driver. }\end{array}$ \\
\hline 21 & $\begin{array}{l}\text { Kisah } \\
\text { Sejati }\end{array}$ & $\begin{array}{l}\text { Kisah Lelanange Jagad, } \\
\text { Tiga Istri Bos Berhasil } \\
\text { 'Dibongkar'; Balada } \\
\text { Pernikahan Sejenis, } \\
\text { Malam Pertama Gagal } \\
\text { Lantaran 'Miliknya' } \\
\text { Sama. }\end{array}$ & $\begin{array}{l}\text { Contains the story of infidelity } \\
\text { and the discovery of similar } \\
\text { mode of marriage fraud. }\end{array}$ \\
\hline 27 & Manca & $\begin{array}{l}\text { Bos Playboy Meninggal, } \\
\text { Puluhan Model Seksi } \\
\text { Ditiduri. }\end{array}$ & $\begin{array}{l}\text { Contains the death of Hugh } \\
\text { Hefner who like to have sex with } \\
\text { dozens of sexy models. }\end{array}$ \\
\hline $\begin{array}{l}28- \\
29\end{array}$ & $\begin{array}{l}\text { Mantra } \\
\text { XXX }\end{array}$ & $\begin{array}{l}\text { Mengintip Lokalisasi } \\
\text { Pinggiran Alas Roban } \\
\text { Jateng, Langganan } \\
\text { Para Sopir, Dua Ratus } \\
\text { Ribu Sekali Kencan; } \\
\text { Empat Lokalisasi di } \\
\text { Batang-Pekalongan dan } \\
\text { Sekitarnya; Mitos } \\
\text { "Nakal" Sopir, Yen } \\
\text { Ngaso Mampir. }\end{array}$ & $\begin{array}{l}\text { Contains reports of commercial } \\
\text { sex worker centers in Batang, } \\
\text { Tegal, Brebes, and Semarang } \\
\text { which are generally the center of } \\
\text { "snack" of the drivers. }\end{array}$ \\
\hline
\end{tabular}




\begin{tabular}{llll}
\hline Page & $\begin{array}{l}\text { Name of } \\
\text { Rubric }\end{array}$ & Title of News & Content/Discription \\
\hline 30 & $\begin{array}{l}\text { Jeritan } \\
\text { Hati/Na } \\
\text { lo }\end{array}$ & $\begin{array}{l}\text { Pengakuan Mantan } \\
\text { Primadona Dolly } \\
\text { (7-Habis), Lepas dari } \\
\text { Salon Plus Terjun } \\
\text { ke Lokalisasi. }\end{array}$ & $\begin{array}{l}\text { Contains the story of a } \\
\text { Commercial Sex Worker }\end{array}$ \\
\hline 31 & $\begin{array}{l}\text { Bandot } \\
\text { Nalo }\end{array}$ & $\begin{array}{l}\text { Petualangan Bandot } \\
\text { Pemburu Janda, }\end{array}$ & Contains a story of infidelity. \\
& & $\begin{array}{l}\text { Dibikin Hamil Dua } \\
\text { Kali Hingga Ditinggal } \\
\end{array}$ & \\
\hline 32 & Kabur. & \\
& Iklan & $\begin{array}{l}\text { Iklan obat kuat, iklan } \\
\text { paranormal, dll. }\end{array}$ & $\begin{array}{l}\text { Contains ads of Herbal products; } \\
\text { where some advertising is a drug } \\
\text { virility as well as promising to } \\
\end{array}$ \\
& & cure various diseases. \\
& &
\end{tabular}

Based on content analysis on the Mantra Tabloid of 170th edition, it can be deduced that the content presented is full of sex exploitation, especially making women as the object of sex. Pornographic news can be easily detected from making erotic titles, photo- tending photo support that is likely to be vulgar, citing statements from dramatic sources, and sentence descriptions and word choices. Based on the above findings, clearly and decisively, the content of the Mantra Tabloid of 170th edition above violates the following regulation:

First, Law Number 40/1999 regarding Press namely:

- Article 5, paragraph 1: "The national press is obliged to proclaim events and opinions by respecting religious norms and the sense of public morality and the presumption of innocence".

- Article 7 paragraph 2: "Journalists have and obey the Code of Ethics of Journalism".

- Article 13 point a: "Press companies are prohibited from publishing advertisements: which degrade the dignity of a religion or interfere with the harmony of life among religious believers, as well as contrary to the sense of public morality".

Second, the Law of the Republic of Indonesia Number 44/2008 on 
Pornography namely:

- Article 4 paragraph 1, a, b and d: "Every person is prohibited from producing, making, reproducing, copying, distributing, broadcasting, importing, exporting, offering, trading, leasing or otherwise providing pornography explicitly containing: deviant sexual abuse, and nudity or impressive display of nudity.

- Article 4 paragraph 2, a, c and d: "Everyone is prohibited from providing pornographic services that: explicitly display nudity or nudity, exploit or display sexual activity, and or offer or advertise, directly or indirectly sexual".

Third, Press Council Regulation Number: 6/Regulation-DP/V/2008 About Ratification of Press Council Letter Number 03/SK- DP/III/2006 on Journalistic Code of Ethics As a Press Council Regulation Article 4: "Indonesian journalists do not make false news, slander, sadist, and lewd ". Cabul means erotic behavioral depiction with photos, pictures, sounds, graphics or writing solely for arousing lust.

Fourth, Press Council Regulation Number: 8/Regulation-DP/X/2008 About Guidelines for Spread of Adult Special Print Media. "That adult print media is a publication containing material in the form of writing or images, which contain sex, violence, and mysticism that should only be consumed by adults aged 21 years or older, the dissemination of adult media is not done in an affordable place for children. children, school environment and places of worship, adult media managers are required to cover part of the front and back cover of their publications so that only media names, edition numbers and adult labels $21+$ are displayed, adult adult media referring to the above points: closes part of the front and back cover of the publication so that only media names, edition numbers, and adult labels $21+$ are displayed".

Relying on Law Number 40/1999 on the Press; that the public has the right to actively monitor and report a press violation to the Press Council. This is relevant with Law Number 40/1999 Article 17 paragraph 1-2: 1) The public may engage in activities to develop press freedom and guarantee the right to obtain necessary information 2) The activities referred to in paragraph (1) may be: a) Monitor and report analysis on violations of the law, and technical misrepresentation of news made by the press; $b$ submits suggestions and suggestions to the Press Council in order to safeguard and improve the quality of the national press ". At the same time it is in accordance with the Law of the Republic of Indonesia Number 44/2008 on Pornography Article 20: "The 
public can participate in preventing the manufacture, dissemination and use of pornography”. And relevant to the Press Council Regulation Number 8/ Regulation-DP/X/2008 About the Adult Special Print Media Spread Guidelines that: "The public may file a complainant media manager who violates this Code to the Press Council”.

That government/local government is also obliged to prevent the making, dissemination, and use of pornographic media. This is in accordance with the Law of the Republic of Indonesia Number 44/2008 on Pornography Article 17: "The government and the regional government are obliged to prevent the manufacture, dissemination and use of pornography".

That based on Law Number 40/1999 on the Press Article 18 paragraph 2: "Companies that are in violation of the provisions of Article 5 paragraph (1) and paragraph (2), and Article 13 shall be liable to a fine of not more than $\mathrm{Rp}$ 500,000,000 (five hundred million rupiahs)".

Whereas Law Number 44/2008 on Pornography Article 29 and 30: "Any person who produces, reproduces, reproduces, distributes, broadcasts, imports, exports, offers, sells, leases or provides pornography as referred to in Article 4 paragraph (1) shall be subject to imprisonment of a minimum of 6 (six) months and a maximum of 12 (twelve) years or a fine of at least $R p$ 250,000,000 (two hundred and fifty million rupiah) and a maximum of $\operatorname{Rp} 6,000,000,000$ (six billion rupiah). Any person providing pornographic services as referred to in Article 4 paragraph

(2) shall be sentenced with a minimum imprisonment of 6 (six) months and a maximum of 6 (six) years or a fine of at least Rp 250,000,000 (two hundred and fifty million rupiah) and a maximum of $\operatorname{Rp} 3,000,000,000.00$ (three billion rupiahs)".

\section{Attitude of the Press Council on Case of Mantra Tabloid of 170th Edition}

Based on the above content analysis results, the researcher pursues the legal path of making a written complaint on the Mantra Tabloid to the Press Council on November 10, 2017. On December 5, 2017, the Press Council invited researchers and leaders of the Mantra Tabloid in the Press Council Secretariat. But the Mantra Tabloid is not present, without any reason. At the time of the first call, the researcher brought a number of important documents, including the Mantra Tabloid of 170th edition and several editions before and after. 
On December 12, 2017, again the Press Council invited the Mantra Tabloid party for clarification, but for the second time they did not attend without confirmation again.

On the case, then the Press Council issued a letter Number: 240b/ DP/K/V/2018 about the Warning to Mantra Tabloid on May 15, 2018. The contents, that pornography and obscenity are not included in the press category. The press disseminates information relating to the public domain, whereas pornography and obscenity are related to private areas (personal). That the press does not broadcast information and visual products by indulging in pornography and obscenity. The Press Council considers that the Mantra

Tabloid violates Item 3 of the Regulation Guideline of Press Council Number 8/Regulation-DP/X/2008 on Guidelines for the Distribution of Adult Special Print Media which reads: The management of adult media must cover part of the front and back cover of the publication so that only name media, edition number and adult label $21+$.

On the verdict of the Press Council, the researcher is not satisfied with the sanction given very light in the form of written warning only. Moreover, based on the above verdict, Mantra Tabloid did not violate the Law Number 40/1999 about the Press. The Press Council which does not have the authority to prosecute the concerned to the court, becomes a weakness of the institution. Delays and waiting for complaints from the community are also a weakness of the institution. The Press Council as the supreme supervisory agency in the press media industry should be committed to upholding press law in Indonesia. That pornography is not only a matter of journalism (press), but also contains a criminal element (see Law Number 40/1999 on Press Articles 4, 5, 9, 13). That is, if the Press Council is not revolutionary in upholding the law, anything severe of the Mantra Tabloid will never violate the Law on the Press.

\section{Conclusion}

The Mantra Tabloid began in April 2018, unpublished, predicted because of the impact of the complainant's letter and the reprimand from the Press Council, a blend of community movements and the Press Council movement. In an increasingly apathetic and non-critical society of media content, public awareness for media literacy should always be echoed. Obviously the Mantra Tabloid is loaded with pornographic content because some of its pages exploit news and information about sex. Support photos and bombastic titles and make 
women as the main photo on the cover of the tabloids, including in the front pages, making women as sexual objects as well as "sexual victims" themselves. Tabloid Mantra commits the process of commodifying sexual content into merchandise to attract readers to purchase the tabloids. Including to hook the advertisers. Although the Press Council, the pornographic news presented by the Mantra Tabloid, by the Press Council declared not to violate the Law on the Press, only violated the Press Council Regulation Number 8 PeraturanDP/X/2008 concerning Guidelines for the Distribution of Adult Special Print Media. The decision was not strict. Whereas the criminal sanctions inherent in the Law of the Republic of Indonesia Number 40/1999 concerning the Press, especially the violations in Articles 5 and 13 (criminal) are not executed properly.

The Press Council is not strict in its efforts to enforce press laws primarily on cases of pornography. Reflecting on the case of pornography in the Mantra Tabloid above, the Press Council acts slowly, simply waiting for complaints from the public, and has no representation in the region. As a result, the performance of the Press Council is not optimal. If the public relies only on the Press Council to address pornographic issues in print, it is clearly not effective enough. The most effective movement to tackle the problem of pornography is from the public and from internal media workers themselves. The researcher believes that in addition to violating Law Number 40/1999, Tabloid Mantra also violated two other regulations, namely: Law Number 44/2008 on Pornography, and Press Council Regulation Number 6/Peraturan-DP/V/2008 on Ratification of Decision Letter of the Press Council Number 03/SK-DP/III/2006 regarding Journalistic Code of Ethics. To prove it, in the future it must be proven through court.

Apart from that, although the researcher's demands on the Mantra Tabloid through the Press Council are still largely unaddressed: drawing the Mantra Tabloid of 170th edition from the market, drawing circulation Mantra Tabloid before 170th edition (read: issue 1 to 169) from the market because containing content similar to that of 170th edition, instructs the management of Mantra Tabloid (P.T. Ubedde Media Adhiwarta) to apologize to all Indonesian readers (public) for journalistic violations committed through a number of print media in Indonesia; instruct the management of Mantra Tabloid (P.T. Ubedde Media Adhiwarta) to comply with and comply with the press regulations; and prosecute justly responsible corporate Mantra Tabloid in accordance with applicable judicial law in Indonesia. Thankfully, the Mantra Tabloid is not published yet. 


\section{Acknowledgment}

Thank you very much to: Chair of the Press Council, Chairman of College of Communication Studies of Yogyakarta (STIKOM) and Chair of the Center for Research and Community Service to STIKOM Yogyakarta who has funded this research. International Conference on Social Sciences and Education Committee (2nd ICSSED) Yogyakarta State University.

\section{References}

Bisri, A., \& Munawwir A. F. (1999). Dictionary of Indonesia-Arab-Arabic Indonesia al-Bisri. Surabaya: Publisher Pustaka Progresif.

Bungin, B., WS, A. M., \& Alimi, A. S. (2001). Imaji media massa: Konstruksi dan makna realitas sosial iklan televisi dalam masyarakat kapitalistik. Yogyakarta, Jendela.

Cross, M. (1996). Reading television texts: The postmodern language of advertising. Advertising and Culture: Theoretical Perspectives, 1-10.

Keputusan Dewan Pers, February 3, 2012.

Keputusan Dewan Pers, No. 240b/DP/K/V/2018.

Echols, J. M., \& Shadily, H. (1992). An English-Indonesian Dictionary (Kamus Inggris Indonesia). Jakarta: PT Gramedia.

Eriyanto. (2011). Analisis isi: Pengantar metodologi untuk penelitian ilmu komunikasi dan ilmu-ilmu sosial lainnya. Jakarta: Kencana Prenada Media Group.

Peraturan Pemerintah (PP_ No. 18/2014 tentang Lembaga Sensor Film.

UU No. 32/2002 tentang Penyiaran.

UU No. 40/1999 tentang Pers.

UU No. $44 / 2008$ tentang Pornografi.

Mangunsuwito, S. A. (2002). Kamus Lengkap Bahasa Jawa: Jawa-Jawa, JawaIndonesia, Indonesia-Jawa. Yrama Widya.

Martadi, M. (2001). Citra perempuan dalam iklan di majalah femina edisi tahun 1999 kajian semiotik terhadap nilai-nilai gender dalam desain iklan. Nirmana, 3(2).

Peraturan Dewan Pers Nomor 6/Peraturan-DP/V/2008 Tentang Pengesahan Surat Keputusan Dewan Pers Nomor: 03/SK-DP/III/2006 Tentang Kode Etik Jurnalistik sebagai Peraturan Dewan Pers. 
Pornography in print media: Legal review of pornographic content on Mantra ... (Supadiyanto Supadiyanto)

Peraturan Dewan Pers Nomor 8/PERATURAN-DP/X/2008 Tahun 2008 Tentang Pedoman Penyebaran Media Cetak Khusus Dewasa

Ritlinger, H,(1972). The photography and the nude, The Focal Press Gread Britain

Suharko. (1998). "Budaya konsumen dan citra perempuan dalam media massa," dalam Idi Subandy Ibrahim-Hanif Suranto. (ed) Wanita dan media, Konstruksi ideologi gender dalam ruang publik Orde Baru. Bandung: Rosdakarya.

Supadiyanto, S. (2015). Implementasi Program Siaran Lokal pada Stasiun Televisi di Daerah Istimewa Yogyakarta. An-Nida: Jurnal Komunikasi Islam, 7(2).

Chulsum, U., \& Novia, W. (2006). Kamus besar Bahasa Indonesia. Surabaya: Kashiko.

Widyatama, R. (2009). Pengantar periklanan, Yogyakarta: Pustaka. 
Journal of Social Studies (JSS), Volume 15, Number 1, 2019: 47-62 